\title{
SULUH
}

JURNAL BIMBINGAN DAN KONSELING

http://journal.umpalangkaraya.ac.id/index.php/suluh Volume 5 Nomor 1, September 2019 (12-17)

\section{MENINGKATKAN ETOS KERJA GURU MELALUI BIMBINGAN BERKELANJUTAN DI SDN-1 SUKA MAKIMUR} Improving Teacher's Work Ethics Through Sustainable Guidance At SDN-1 Suka Makmur Mariman

SDN I Suka Makmur, Kotawaringin Barat, Kalimantan Tengah, Indonesia

\section{ARTIKEL INFO}

Diterima

Dipublikasi September 2019 *e-mail :

Orcid :

\section{ABSTRAK}

Tujuan penelitian ini adalah untuk (I) melihat apakah terjadi peningkatan etos kerja guru melalui bimbingan berkelanjutan. (2) Kegiatan bimbingan berkelanjutan untuk meningkatkan etos Kerja Guru SDN-I Suka Makmur berjalan lancar dan sesuai harapan. Metode penelitian yang dilakukan adalah Penelitian Tindakan Sekolah.

Hasil observasi yang di lakukan pada siklus I terdapat sekitar $60 \%$ guru yang dapat meningkatkan etos kerjanya. Sementara hasil observasi pada siswa terdapat sekitar 65 \% siswa yang aktif dalam pembelajaran. Dari hasil tersebut dapat disimpulkan bahwa kegiatan kegiatan bimbingan berkelanjutan berjalan dengan lancar meskipun hasil yang didapatkan pada siklus I belum memuaskan. Dari hasil observasi siklus 2 terdapat sekitar $90 \%$ guru yang meningkat etos kerjanya. Sementara hasil observasi pada siswa menunjukan bahwa $87 \%$ siswa meningkat keaktifan belajarnya. Dari hasil observasi siklus I dan sikul 2, dapat di nyatakan bahwa ada peningkatan etos Kerja Guru dari siklus I ke siklus 2, juga terdapat peningkatan keaktifan belajar siswa dari siklus I ke siklus 2. Maka Kegiatan kegiatan bimbingan berkelanjutan mampu meningkatkan etos Kerja Guru SDN-I Suka Makmur.

Kata kunci: Etos Kerja Guru, Bimbingan Berkelanjutan.

\section{ABSTRACT}

The purpose of this study is to (I) see whether an increase in the work ethic of teachers through ongoing guidance. (2) Continuing guidance activities to improve the Work Ethic of Teachers of SDN-I Suka Makmur run smoothly and as expected. The research method used is School Action Research.

The results of observations made in cycle $I$, there are about $60 \%$ of teachers who can improve their work ethic. While the results of observations on students there are about $65 \%$ of students who are active in learning. From these results it can be concluded that the activities of ongoing guidance activities run smoothly even though the results obtained in cycle I have not been satisfactory. From the results of observations of cycle 2, there were about $90 \%$ of teachers who improved their work ethic. While the results of observations on students showed that $87 \%$ of students increased their learning activeness. From the results of observations of cycle $I$ and cycle 2, it can be stated that there was an increase in the Teacher's Work ethic from cycle $I$ to cycle 2, there was also an increase in student learning activeness from cycle I to cycle 2. Then the activities of ongoing guidance activities were able to improve the Teacher's Work Ethic in SDN- I Love Prosperous.

Keywords: Teacher's Work Ethic, Continuous Guidance.

(C) Universitas Muhammadiyah Palangkaraya 
Jurnal Bimbingan dan Konseling

PENDAHULUAN

Pendidikan selalu berkenaan dengan upaya pembinaan manusia. Keberhasilan pendidikan sangat tergantung pada unsur manusianya. Paling menentukan keberhasilan pendidikan adalah pelaksanaannya yaitu para pendidik khususnya guru. Guru merupakan ujung tombak pendidikan. Sebagai pendidik secara langsung berupaya mempengaruhi, membina dan mengembangkan kemampuan siswa agar menjadi manusia yang cerdas, terampil dan bermoral tinggi. (Sudjana, 1996: 2).

Untuk menjadi guru yang profesional, guru harus memenuhi kualifikasi akademik minimum dan sertifikasi sesuai jenjang kewenangan mengajar. (amanat UU No. 20 tahun 2003 pasal 42 dan PP No. 29 tahun 2005 Bab VI pasal 28). Program sertifikasi kepada guru akan menjadi kontrol yang mendorong para penyelenggara pendidikan untuk meningkatkan profesionalismenya dan memberikan layanan maksimal kepada para stakeholder. Gaffar (Sumaryani, 2008:5) mengemukakan bahwa "sertifikasi dalam sistem pendidikan guru adalah proses pendidikan yang mencakup program D4, S2 dan pendidikan profesi”

Etos kerja merupakan karakter dan kebiasaan berkenaan dengan kerja yang terpancar dari sikap hidup manusia yang mendasar terhadapnya. Etos Kerja Guru sangat penting untuk dimiliki oleh seorang pendidik, sebab tanpa etos kerja yang tinggi, mustahil tujuan pendidikan yang telah dikemukakan sebelumnya akan tercapai.

Fenomena inilah yang sangat menarik untuk dikaji dan diteliti secara mendalam untuk mengetahui yang sebenarnya apakah yang terjadi tentang etos Kerja Guru. Setiap sekolah tentu sangat mengharapkan adanya guru yang memiliki etos kerja yang tinggi. Begitu pula yang terjadi SDN-I Suka Makmur Salah satu cara untuk meningkatkan etos Kerja Guru SDN-I Suka Makmuryaitu dengan bimbingan berkelanjutan. Bimbingan berkelanjutan di artikan sebagai bantuan yang diberikan kepada individu untuk dapat memilih, mempersiapkan diri dan memangku suatu jabatan dan mendapat kemajuan dalam jabatan yang dipilihnya.

Dalam upaya meningkatkan etos Kerja Guru, menurut Wahjosumidjo (1999:92), bahwa "kepala sekolah adalah seorang yang dapat menentukan titik pusat dan irama suatu sekolah". Jika kepala sekolah cakap maka tentunya akan besar perhatiannya pada etos kerja baik yang menyangkut guru maupun peserta didik sejak masuk sekolah sampai dengan kembali kerumah masing-masing. Kepala sekolah juga berpikir dan berusaha bagaimana guru merasa nyaman di sekolah, senang dalam bekerja dan memperoleh kesejahteraan yang memadai.

Dalam meningkatkan etos kerja, guru senantiasa diperhadapkan pada peningkatan kualitas pribadi dan sosialnya. Jika hal ini dapat dipenuhi maka keberhasilan lebih cepat 
Jurnal Bimbingan dan Konseling

diperoleh, yaitu mampu melahirkan peserta didik yang berbudi luhur, memiliki karakter sosial dan profesional sebagaimana yang menjadi tujuan pokok pendidikan itu sendiri.

"Etos" dari sudut pandang bahasa berasal dari bahasa Yunani "ethos" yang bermakna watak atau karakter. Dalam Kamus Besar Bahasa Indonesia (1993:27I) makna lengkap "etos" adalah "karakteristik, sikap, kebiasaan, kepercayaan, dan seterusnya, yang bersifat khusus tentang individu atau sekelompok manusia".

Dalam Webster's News World Dictionary of the American Languange (1980) dikemukakan istilah "etos" berhubungan dengan "etika”, "etis", yakni "kualitas esensial seseorang atau suatu kelompok atau organisasi." Sedangkan (Echols dan Shadily 1994;219) mengartikan “etos" sebagai jiwa khas suatu kelompok manusia. Berdasarkan jiwa yang khas itulah berkembang pandangan seseorang individu atau kelompok (organisasi) tentang sesuatu yang baik dan sesuatu yang buruk.

Etos kerja dalam Kamus Besar Bahasa Indonesia (1993:27I) diartikan sebagai "semangat kerja yang menjadi ciri khas dan keyakinan seseorang atau sesuatu kelompok". Dalam pengertian seperti inilah, maka negara industri baru (INC = Newly Industrializing Countries) seputas Indonesia, yaitu Korea Selatan, Taiwan, Hongkong, dan Singapore, seringkali disebut sebagai "Little Dragong" (naga-naga kecil). Maksudnya, NIC adalah negara konfusionis, yaitu penganut ajaran Kong $\mathrm{Hu} \mathrm{Cu}$, dengan naga sebagai binatang mitologis dalam sistem kepercayaan mereka.

Frank Parson. menyatakan, "bimbingan sebagai bantuan yang diberikan kepada individu untuk dapat memilih, mempersiapkan diri dan memangku suatu jabatan dan mendapat kemajuan dalam jabatan yang dipilihnya." Chiskon menyatakan, "bimbingan membantu individu untuk lebih mengenal berbagai informasi tentang dirinya sendiri."

Berikutnya Bernard dan Fullmer 1969 menyatakan, "bahwa bimbingan dilakukan untuk meningkatkan perwujudan diri individu." Dapat dipahami bahwa bimbingan membantu individu untuk mengaktualisasikan diri dengan lingkungannya. Menurut Tim Redaksi Kamus Besar Bahasa Indonesia, "bimbingan adalah petunjuk penjelasan cara mengerjakan sesuatu, tuntutan."

Dari beberapa pengertian bimbingan di atas, dapat ditarik kesimpulan bahwa bimbingan adalah pemberian bantuan kepada individu secara berkelanjutan dan sistematis yang dilakukan oleh seorang ahli yang telah mendapat latihan khusus untuk itu,dimaksudkan agar individu dapat memahami dirinya, lingkungannya, serta dapat mengarahkan diri dan menyesuaikan diri dengan lingkungan untuk dapat mengembangkan potensi dirinya secara optimal untuk kesejahteraan dirinya dan kesejahteraan masyarakat. Menurut Redaksi Kamus Besar Bahasa Indonesia, Edisi Kedua, 
Jurnal Bimbingan dan Konseling

"berkelanjutan adalah berlangsung terus menerus, berkesinambungan."

Berdasarkan pengertian bimbingan dan berkelanjutan dapat ditarik suatu kesimpulan bahwa bimbingan berkelanjutan adalah pemberian bantuan yang diberikan seorang ahli kepada seseorang atau individu secara berkelanjutan berlangsung secara terus menerus untuk dapat mengembangkan potensi dirinya secara optimal dan mendapat kemajuan dalam bekerja.

\section{METODOLOGI PENELITIAN}

Jenis penelitian yang dilakukan adalah Penelitian Tindakan Sekolah. Penelitian ini dilakukan dalam 4 tahapan, yaitu persiapan, pelaksanaan dan evaluasi dan refleksi, dan dilakukan minimal dalam dua siklus. Pada tahap persiapan dibuat dibuat skenario kegiatan, jadwal waktu, tempat serta sarana pendukung lainnya seperti lembar observasi.

Penelitian ini ditujukan kepada guru guru semua mata pelajaran baik yang memiliki latar belakang pendidikan keguruan maupun yang tidak memiliki latar belakang pendidikan keguruan yang berjumlah 17 orang.

Langkah-langkah PTS yaitu: perencanaan, pelaksanaan, pengamatan, dan refleksi. Langkah-langkah PTS seperti Gambar I berikut:

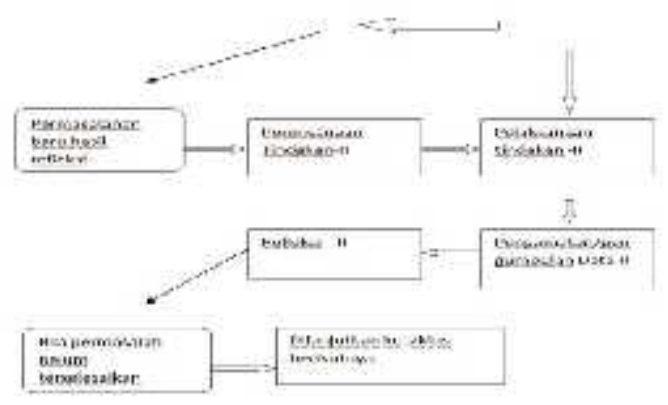

Gambar I

Langkah-langkah PTS

Teknik pengumpulan data yaitu alat untuk memperoleh data dan alat ini harus sesuai dengan jenis data yang diinginkan. Teknik pengumpulan data pada penelitian ini menggunakan teknik non tes. Teknik nontes merupakan teknik pengumpulan data yang tidak baku dan hasil rekayasa dari guru dan sekolah. Adapun kegunaan teknik nontes ialah untuk mengumpulkan data yang tidak dapat dikumpulkan dengan teknik tes, seperti kebiasaan belajar siswa baik di sekolah maupun di rumah, keterangan orangtua dan lingkungannya mengenai diri siswa, dan lainnya. Teknik nontes yang akan kita bahas bersama dalam unit 4 ini adalah: observasi, angket, wawancara,. Dengan instrument non tes ini akan meningkatkan etos kerja guru.

\section{HASIL DAN PEMBAHASAN}

Dari hasil observasi yang di lakukan pada siklus I terdapat sekitar $60 \%$ guru yang dapat meningkatkan etos kerjanya. Sementara hasil observasi pada siswa terdapat sekitar 65 \% siswa yang aktif dalam pembelajaran. Dari 
hasil tersebut dapat disimpulkan bahwa kegiatan kegiatan bimbingan berkelanjutan berjalan dengan lancar meskipun hasil yang didapatkan pada siklus I belum memuaskan.

Dari hasil observasi siklus 2 terdapat sekitar 90\% guru yang meningkat etos kerjanya. Sementara hasil observasi pada siswa menunjukan bahwa $87 \%$ siswa meningkat keaktifan belajarnya. Dari hasil observasi siklus I dan sikul 2, dapat di nyatakan bahwa ada peningkatan etos Kerja Guru dari siklus I ke siklus 2, juga terdapat peningkatan keaktifan belajar siswa dari siklus I ke siklus 2. Maka Kegiatan kegiatan bimbingan berkelanjutan mampu meningkatkan etos Kerja Guru SDN-I Suka Makmur. Berikut adalah grafik perbandingan jumlah skor siklus I dan Siklus II:

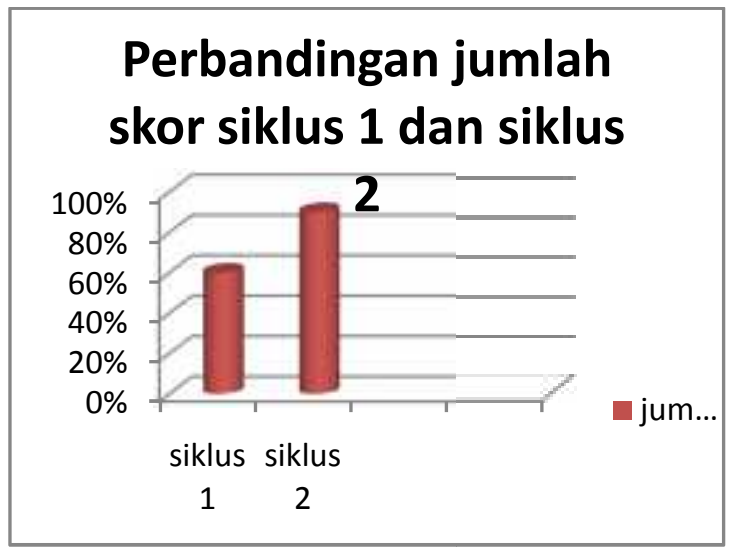

Grafik I

Perbandingan Hasil Pada Siklus I dan Siklus 2 Pengamatan Terhadap Guru

\section{KESIMPULAN}

Dari Proses Penelitian Tindakan sekolah yang di lakukan SDN-I Suka Makmur yang berjudul Implementasi Kegiatan Kegiatan bimbingan berkelanjutan Dalam Meningkatkan Etos Kerja Guru SDN-I Suka Makmur Tahun 2017 dapat disimpulkan bahwa terjadi peningkatan etos Kerja Guru dari siklus I ke siklus 2. Kegiatan Kegiatan bimbingan berkelanjutan untuk meningkatkan etos Kerja Guru SDN-I Suka Makmurberjalan lancar dan sesuai harapan. Melihat data perolehan hasil penelitian dalam kegiatan penelitian tindakan sekolah ini, dapat disimpulkan bahwa kegiatan bimbingan berkelanjutan yang dilakukan oleh kepala sekolah terhadap 17 orang guru SDNI Suka Makmur tersebut, berhasil meningkatkan etos Kerja Guru.

Berdasarkan kesimpulan di atas, maka peneliti membuat saran-saran yaitu kegiatan- kegiatan bimbingan berkelanjutan sangat baik dilakukan untuk membina guru meningkatkan etos kerja, sebaiknya kegiatan ini dilaksanakan secara terencana dan berkesinambungan. Sebaiknya pembinaan ini dilanjutkan dengan kegiatan bimbingan berkelanjutan dalam pelaksanaan pembelajaran untuk mengukur etos Kerja Guru dalam mengimplementasikan rencana pembelajaran yang telah disusunnya. Supervisi juga dilakukan terhadap semua guru secara bergilir dan menyangkut seluruh aspek kemampuan/ kompetensi guru.

\section{DAFTAR PUSTAKA}

Departemen Pendidikan dan Kebudayaan RI. 1982. Alat Penilaian Kemampuan Guru: 
Jurnal Bimbingan dan Konseling

Buku I. Jakarta: Proyek Pengembangan

Pendidikan Guru. 1982. Panduan Umum Alat Penilaian Kemampuan Guru. Jakarta: Proyek Pengembangan Pendidikan Guru Alat Penilaian Kemampuan Guru: Hubungan antar Pribadi.Buku III. Jakarta: Proyek Pengembangan Pendidikan Guru.

Alat Penilaian Kemampuan Guru:

Prosedur Mengajar. Buku II. Jakarta:

Proyek Pengembangan Pendidikan

Guru.

Suhardjono, A. Azis Hoesein, dkk. 1995.

Pedoman penyusunan KTI di Bidang Pendidikan dan Angka Kredit Pengembangan Profesi Guru. Digutentis, Jakarta : Diknas

Pidarta, Made. 2009. Supervisi Pendidikan Kontekstual. PT. Rineka Cipta: Jakarta Satori, Djam'an. 2004. Paradigma Baru Supervisi Pendidikan untuk Meningkatkan Mutu dalam Konteks Peranan Kepala sekolah dalam otonomi Daerah.ASPI : Jaba

Suhardjono. 2005. Laporan Penelitian Eksperimen dan Penelitian Tindakan Kelas sebagai KTI, makalah pada Pelatihan Peningkatan Mutu Guru di LPMP Makasar, Maret 2005

Suhardjono. 2009. Tanya jawab tentang PTK dan PTS, naskah buku.

Suharsimi, Arikunto. 2002. Penelitian Tindakan Kelas, Makalah pada
Pendidikan dan Pelatihan (TOT) Pengembangan Profesi bagi Jabatan Fungsionla Guru, II-20 Juli 2002 di Balai penataran Guru (BPG) Semarang. Suharsimi, Suhardjono dan Supardi. 2006. Penelitian Tindakan Kelas. Jakarta : PT Bumi Aksara

Supardi. 2005. Penyusunan Usulan, dan Laporan Penelitian Penelitian Tindakan Kelas, Makalah disampaikan pada "Diklat Pengembangan Profesi Widyaiswara", Ditektorat Tenaga Pendidik dan Kependidikan Dirjen Pendidikan Dasar dan Menengah, Departemen Pendidikan Nasional. 